\title{
Urgent Matter
}

Jonathan Monroe

Cornell University

Opening questions about "things" onto the bureaucratically-maintained, compartmentalized discursive, disciplinary claims of "philosophy," "theory," and "poetry," "Urgent Matter" explores these three terms in relation to one another through attention to recent work by Giorgio Agamben, Jacques Rancière, the German-American poet Rosmarie Waldrop, and the German poet Ulf Stolterfoht, whose fachsprachen. Gedichte. I-IX (Lingos I-IX. Poems) Waldrop rendered into English in an award-winning translation. The difference between the "things" called "poetry" and "philosophy," as now institutionalized within the academy, is not epistemological, ontological, ahistorical, but a matter of linguistic domains, of so-called concrete "images" as the policed domain of the former and of "abstraction" as the policed domain of the latter. Challenging the binary logics that dominate language use in diverse discursive/disciplinary cultures, Waldrop's linguistically self-referential, appositional procedures develop ways to use language that are neither linear, nor so much without direction, as multidirectional, offering complexes of adjacency, of asides, of digression, of errancy, of being "alongside," in lieu of being "opposed to," that constitute at once a poetics, an aesthetics, an ethics, and a politics. Elaborating a complementary understanding of poetry as "the most philosophic of all writing," a medium of being "contemporary," Waldrop and Stolterfoht question poetry's purposes as one kind of language apparatus among others in the general economy. Whatever poetry might be, it aspires to be in their hands not a thing in itself but a form of self-questioning, of all discourses, all disciplines, that "thing" that binds "poetry" and "philosophy" together, as urgent matter, in continuing.

Jonathan Monroe's recent articles and book contributions include his forthcoming chapter on "Genre" for Literature Now: Key Terms and Methods for Literary History (2015); "Poetry, Philosophy, Parataxis"; "Composite Cultures, Chaos Wor(I)ds: Relational Poetics, Textual Hybridity, and the Future of Opacity"; "Autrement Dire: La poussée vers l'abstraction de Rosmarie Waldrop"; "Los amores y juegos del joven Berger" (in Bolaño Salvaje); and "Every Person, Many Studies" (in the ADFL Bulletin). Professor of Comparative Literature at Cornell University, he is the author of A Poverty of Objects: The Prose Poem and the Politics of Genre; Demosthenes' Legacy, a collection of prose poems and short fiction; and co-author and editor of two special issues on modern and contemporary poetry - Poetry, Community, Movement (Diacritics), and Aftershock: Poetry and Cultural Politics since 1989 (Poetics Today)—as well as two books on writing in the academy: Writing and Revising the Disciplines and Local Knowledges, Local Practices: Writing in the Disciplines at Cornell. His verse and prose poetry, short fiction, and cross-genre writing have appeared as well in numerous journals, including The American Poetry Review, Epoch, 
Harvard Review, /nor New Ohio Review, Verse, Volt, and Xcp: Cross-Cultural Poetics. A former DAAD Fellow at the Universität Konstanz, he has served as a steering committee member of Cornell's Institute for German Cultural Studies; as a member of the Fulbright selection committee; and as Director of Cornell's John S. Knight Institute for Writing in the Disciplines. His current research focuses on contemporary poetry and poetics in Europe and the Americas.

A poem is primarily an exploration of language.

Rosmarie Waldrop, Dissonance (if you are interested)

This brings us to the difficulties of existence and accepted theories. .... Was the line an illusion at my finger or despair dashing straight at me, en route from Washington to Baghdad?

Rosmarie Waldrop, Driven to Abstraction

Aber nur das zweite drängt mich zum Schreibtisch.

Bertolt Brecht, "Schlechte Zeit

für Lyrik"

\section{The Thing Is}

So a poet, a physicist, and a historical materialist walked into a bar, arriving at the door at exactly the same moment. "After you," said the poet. "After you," said the physicist. "'After you," said the historical materialist. "Let me tell you about your disciplines," said the first. "Let me tell you about your disciplines," said the second. "Let me tell you about your disciplines," said the third. Once inside, as was their custom, they went to their separate corners, each to his own Stammtisch, the first beneath a sign that read Sein, the second beneath a sign that read $D a$, the third beneath a sign that read Mit. Hedgehogs as they were, they drank and thought, thought and drank, until the contours of their reflections 
began to blur, until they fell, each to his own, into a light stupor. At the end of a long evening, seeing no other customers anywhere in sight, the bartender, known simply as "H," or "G," sometimes "W," who was neither a metaphysician, nor a cosmologist, nor a theologian, emerged from behind the counter red-faced, in a lather. "Here's the thing. . ." he said, "The thing is. .."-Which one of you hipsters - he might have said disciples, disciplinarians, seminarians - is going to pay off this enormous debt!"

The first thing to be said about the question "What is a Thing?" may be that it inscribes within itself a constitutive binary, the familiar, foundational sundering of "subject" and "object." In addressing the stakes of this sundering, what I am calling its "urgent matter," I want to ask above all what kind, or genre, the question is. To which discourses, which disciplines, does it belong? Is it, for example, "ontological" or "historical," "cosmological" or "physiological," "psychoanalytic" or "Marxist," "phenomenological" or "linguistic," "philosophical" or "lyrical"? From which angles should we attempt to grasp it, this curious (idea of a) thing? Is it (un)knowable? Can we (re)read it? Can it be (un)read? What approach should we use to get near, keep our distance, steer clear? When will we know that, and what, we know? Will such knowledge be "constative" or "performative"? "Fact" or "interpretation"? Whose question is the question of a thing, anyway, and to whom does it belong? Where does it come from now?

As digital technologies and electronic media have come to inform virtually all current imaginings, or better, accountings, of what Walter Benjamin called the "time of the now" (Jetztzeit), it has become harder than ever to be what Friedrich Schlegel termed a "hedgehog" (ein Igel). In ways Schlegel's Universalpoesie both anticipated and could never have envisioned, the World Wide Web has placed all things, including all discourses and disciplines, in ceaseless, simultaneous, virtual conversation at the click of a mouse, or the swipe of a finger. In this context, the relative autonomy of the aesthetic sphere, including of 
that hedgehog of hedgehogs, "poetry," seems largely a "thing" of the past, relic of a time when the individual could still claim to be, in ways it has become more difficult than ever to claim in the age of social media, the locus of experience in the modern world.

Opening questions about "things" onto the bureaucratically-maintained, compartmentalized, discursive, disciplinary claims of "philosophy," "theory," and "poetry," I want to explore these three terms in relation to one another through attention to recent work by Giorgio Agamben, Jacques Rancière, and the German-American poet Rosmarie Waldrop (born Sébald, 1935), who moved to the United States in 1958 and received a Ph.D. in Comparative Literature from the University of Michigan 1966. The essay's fifth and final section, "Poetry among the Discourses," concludes with brief attention as well to the German poet Ulf Stolterfoht (b. 1963), whose fachsprachen. Gedichte. I-IX (1998; Lingos I-IX. Poems. 2008) Waldrop rendered into English in an award-winning translation published by the influential Burning Deck Press she has run for the past four decades with her husband, the poet and translator, Keith Waldrop.

"A medium," Friedrich Kittler writes in Discourse Networks-echoing Gertrude Stein's famous declaration about that most "poetic" of things, the "rose"- "is a medium is a medium." While the "logic of media," Kittler argues, "may be a truism in set theory or information theory," that logic emerged "for Poets," following the fin-de-siècle preceding our own, as "the surprise of the century":

Before they founded The New Empire, the kingdom of blank machine-written bodies of words, poets more than any other profession [my emphasis] remained faithful to the classical discourse network. The translatability of all discourses into poetic signifieds endowed poets with such privilege that only bitter experience forced them to renounce their constitutive illusions. For an entire century, poets had worked with language as if it were merely a channel. . . . / In 1900, the exchange broke down. The norn with whom a Poet bartered his imaginative visions for 
words is no longer a Mother, the one who, as the unarticulated beginning of articulation, guaranteed unlimited expression. The norn has only a bourn or treasury in which signifiers coexist spatially as denumerable elements. . . Whereas poetic translation was led on by the constant promise of fulfillment, literature is a transposition of media; its structure it first reveals, in the best positivistic and consequently Dasein-analytic manner, by deficits. (265-69)

Deconstructing Heidegger's representation of poetry as the genre that opens onto The Word and/as pure Being, which he rightly understands as a form of late Romanticism, Kittler understands Stefan George's "kein ding sei wo das wort gebricht"-quoted two pages from the end of Waldrop's 2010 Driven to Abstraction before the phrase, "No words, no fact before signs" (131) — as an acknowledgement that "The Word" no longer opens, in poetry any more than in any other kind of discourse, onto transcendental signifieds (Nature, Spirit, the Soul), but onto "the ethic of a media professional" (268). If according to Nietzsche, as Kittler argues, "language exists only because nature has thrown away the keys to its secrets" (269), and if poetry is understood, as Heidegger and Agamben too understand it, as the discourse that comes closest to revealing those secrets, the discourse that possesses the "saving power," in Heidegger's terms (das Rettende), of a certain transcendens, as anti- or non-commodified language, Waldrop's Driven to Abstraction suggests that such transcendence is no more in the offing in poetry than in the discourse of what Kittler calls other "media professionals" (269). While poetry seems constantly to have been placed in the position of having to defend its claims in relation to other discourses and media, the Web has placed those claims in a more precarious position than ever. If "a picture is worth a thousand words," and if poetry is understood to be an "image-saturated" discourse, the ubiquitous availability and circulatability of all other forms of media, of visual images as easily as of words, runs the risk of a precipitous decline in poetry's claims to even a relative autonomy. Who needs metaphorical "images," however sharply defined, however suggestive, when we 
can have the "real" (photographic, filmic, digital) thing, no longer verbal but visual, no longer merely "imaged" in language, but right before our eyes? The instantaneous, endless production, reproduction, and circulation of visual images, as ubiquitous now as words and as readily available, threatens to make metaphorical visualization, metaphors as occasions for visualization, obsolete. Notwithstanding bureaucratically enforced divisions and concentrations within the academy that have come increasingly to seem residual, the consequences of such obsolescence for poetry are enormous, transformative and far-reaching, threatening its very sense of itself as a thing apart from other discourses and media, a "thing" with its own discursively autonomous identity. If in what Benjamin called the "age of mechanical reproduction" (im Zeitalter seiner technischen Reproduzierbarkeit), in Kittler's words, "Man (and woman) no longer need to live by words alone, or by The Word, alone" (269), how much more so in the age of digital reproduction and new media. As the contemporary poet's privilege and authority have become increasingly bureaucratic, managerial, a managing above all of various poetically normative subjectifications, whether individual or collective, personal or tribal, the "object" of poetry, poetry's "thing," its "urgent matter," comes increasingly into question, its claims to cultural authority residing no longer in the promise of revealing transcendental signifieds, but in its discursive, disciplinary status as what Lyn Hejinian has called a "language of inquiry," its status as, in Heidegger's own articulation, a form above all of questioning (das Fragen). Understanding itself no longer apart from other discourses but in relation to them, as what Kittler calls "an information network" among others, "like all literature" (371), poetry faces the need to reposition itself as a kind of system-thinking, network-thinking, no longer the possession of an individual "I."

Recalling Brecht's reflections on what drove him to write poetry in a "dark time"-in "Schlechte Zeit für Lyrik" and "An die Nachgeborenen," respectively_ Waldrop's Driven to Abstraction poses programmatic questions about poetry's relation to "things" in our contemporary context, including the urgent matter of poetry's relation to other discourses and disciplines. The history of "things" in 
modern poetry, as Waldrop understands, is a history of manifestos, of slogans, of "branding." The thing is the brand and the brand is the thing. No things but in brands, no brands but in things. The difference between the "things" called "poetry" and "philosophy," now as institutionalized within the academy, is not epistemological, ontological, ahistorical, but a matter of linguistic domains, of socalled concrete "images" as the policed domain of the former and of "abstraction" as the equally policed domain of the latter. In being "driven to abstraction," not only in her book by that name but throughout her career, Waldrop challenges that institutionalized dichotomy perhaps more resolutely and effectively than any other contemporary poet, encouraging an embrace of both "feeling" and "thinking," of "affect" and "concept," not as contraries, but as mutually constitutive and informing. Not direct presentation of the thing, then, but awareness of the thing as thoroughly mediated. No things but in ideas. No things but in feelings. No feelings, no ideas, no things, but in language: "No things without words, no fact before signs, no specie, no prior body? The signs I write down here preceded by signs preceded by signs? Turtles all the way down? In signs we trust. To build balconies out over the void" (131).

Aligning the "loosely phenomenological" method of his recent Phenomenal Reading: Essays on Modern and Contemporary Poetry (2012) with phenomenology's "widespread resurgence in the humanities" since the 1990s, Brian M. Reed writes that such an approach is "concerned with offering 'a direct description of our experience as it is,' 'an account of space, time, and the world as we 'live' them' (Merleau-Ponty vii)."' Such an account "presumes differential embodiment" in a "perceiving subject" who has "a history and an array of attributes and affiliations that uniquely inflect his or her experience of the world or, to put it more accurately, that prompt the world to disclose itself to him or her in a unique way." This "return to phenomenology" reminds us of the value of narrative as

a tool for conveying the intricacy, contingency, and richness of perceptual and affective experience. Narrative can incorporate paradox, accident, 
and mistake in addition to laying bare causality, logical connection, and the mechanics of moral and ethical judgment. It registers intermittent doubts, changes in perspective, accumulations of knowledge, and alterations in mood. It records facts, counterfactuals, and impossibilities. Deciding what to include and exclude, what to highlight and what to downplay, narrators illustrate their interests, commitments, and zones of ignorance. For all these reasons, a narrative can both educate and persuade a reader. Here, it quietly asserts, is a possible plausible account of an event (or a life or a book) from a particular point of view. Authors can show audiences how they perceive and experience the world, that is, the manner in which, a Heideggerian might say, the world reveals itself to them as a world. (xxi-xxii)

As Reed's emphasis on narrative makes clear-notwithstanding the initial, thoroughly Poundian invocation of a 'direct description of our experience as it is' - "phenomenological" reading reveals nothing "direct" at all about the "thing itself," whether "subjective" or "objective"- to use Pound's terminology—but rather stories about our locations and investments as readers, our reading histories, including, within the academy, our disciplinary locations, of which we can only seek to become as aware as possible. Thus, within the genre, history, discourse, or semantic "field," as we say, of modern poetry-leaving aside for now the question of whether, or in what senses, poetry constitutes an academic "discipline"-while a poem such as Paul Celan's "Weggebeizt" (Atemwende, 1967) may be said to enact an allegorical "chipping away" at the idea of a poem as a coherent, interpretable "thing," its brevity and intensity tend nonetheless to conform, despite its manifest crumbling at the level of both syntax and semantics, to a certain understanding of what is to be expected of a poem as textual object. The simultaneous indebtedness to and dismantling of the tradition of the Dinggedicht, in Celan's later poetry, thus displays as much continuity as discontinuity with received notions of the modern poem as lyric utterance. Recalling Poe's assertion that there is "no such thing as a long poem," Celan 
resists yet also reaffirms, in this sense, a foundational gesture in the history of modern poetry that reached its most succinct articulation in Pound's (AxisPowers inflected) bilingual formulation: "Dichtung = condensare."

Abandoning the limitations of Imagist "condensation" almost as soon as he had articulated its enormously consequential slogans, Pound's "image" poems, like Rilke's Dinggedichte," with all their textual reifications (Verdinglichungen), ultimately only succeed in reopening, however much they might appear to wish to foreclose, the question of the relation between "thing" and "idea" which is also, as Agamben has recently reminded us, a question of the "apparatus." If, as Heidegger posited in "The Question Concerning Technology," the "essence of art" (das Wesen der Kunst), and of poetry as art's quintessence, is questioning [das Fragen], the poem, as thing, as "techné," as "apparatus," is precisely not a form of Verdinglichung, but a thing that reopens itself consistently beyond mere instrumentality, beyond "techné" in the modern sense, to pure poiesis, to the kind of unity Heidegger wanted to claim these terms possessed before their modern sundering from each other (Einstmals trug nicht nur die Technik den Namen techne..., 43). To the extent that poetry may have become, as Mikhail Bakhtin claims in The Dialogical Imagination, the very discourse that cannot question itself, it faces the same challenge other disciplines face-that of resisting its own reification in the name of an ongoing self-questioning.

\section{Prescriptions and Prohibitions}

In the century now passed since the original publication of Ezra Pound's "A Few Don'ts by an Imagist" (Poetry, 1913), an era increasingly defined by U.S. economic and military domination and the expansion of English as a global language, Pound's essay has remained arguably the most programmatic statement in the history of modern poetry, a statement whose seminal definition of the "image" has been at once monumentalized and betrayed in the centurylong history of its reception. Appearing in 2010, three years before Pound's Imagist manifesto's centenary anniversary, Waldrop's Driven to Abstraction offers a powerful coming to terms with that essay's enduring legacy, within a 
transnational, global context, for poetry's complex positioning in relation to other discourses and disciplines.

Calling into question the binary procedures that continue to dominate language use in diverse discursive/disciplinary cultures generally and in the culture at large, the linguistically self-referential, appositional procedures of Waldrop's work contribute to the development of an alternative logic that does not so much "contradict" (speak against) such procedures as offer ways to speak and write otherwise, to use language in ways that are neither linear, nor so much without direction, as multi-directional, a complex of adjacency, of asides, of digression, of errancy, of being "alongside," in lieu of being "opposed to," that constitutes at once a poetics, an aesthetics, an ethics, and a politics.

If modern poetry may be said to have had a single dominant, a persistent if not at times unquestioned, unchallenged hegemonic emphasis extending from Pound's Imagism and Rilke's Dinggedichte even into the first two decades of the current century, it has surely been that of poetry as the cite of the "thing-asimage," of the "image-as-thing," of the "image-thing" or "thing-image" as the sine qua non of the specificity and particularity of what is called "poetry." In introductory survey courses, as in the rapidly multiplying number of creative writing programs and courses - the latter still only beginning to take root in other countries-that have come to play such a pivotal, even dominant role in defining poetry's discursive, disciplinary location within the academy in the United States over the past several decades, modern poetry has sought to establish its bona fides and raison d'être above all as an image-saturated-discourse, as a "discipline" in precisely this sense-or should we perhaps say as an "a-" or "anti," an "in-" or an "other-than" discipline—with an institutional "room of its own."

Yet a funny thing happened on the way to what we might call the age of the "image-thing," or "thing-image." Its dominance, its persistence, its discursive conquest "within" poetry, its ontological, ahistorical claim to be, in effect, what poetry is, what counts, if anything may be said to count, as poetry, has tended to come at the expense, at least in a certain recognizably dominant practice, of half of Pound's inclusive definition of the image as at once "an intellectual and 
emotional complex in an instant of time." While mainstream poetic ideology since the emergence of Imagism and the Dinggedicht—quickly superceded in Pound's own poetic practice by the expansively ambitious, integrally abstract, emphatically cerebral project of The Cantos, Pound's lifelong "poem including history"- -has continued to emphasize the pursuit of original "images" as the mark of a poet's distinction, the complex understanding of the image Pound articulated—at once "intellectual" and "emotional," what might be called these days "conceptual" and "affective"to be subject to a radical reduction, a purging from poetry of abstract, "philosophical" language fully authorized by Pound in what has remained, to the detriment especially of poetry's conceptual capacities, perhaps his most famous imperative: "Go in fear of abstractions."

THE IMPERTINENCE OF EXPLANATION. Immense field of possibilities divided by square roots, the travel through micro-macro rhythm so unpredictable.("Music," 50:12)

... We're now in the glory of not knowing what we're doing. . . ("Music," $52: 14)$

As often as Pound's prohibition has been invoked over the past century in the dutiful instruction of how poetry is to be written and what counts as poetry (an alternate version of which is the ubiquitous "show, don't tell"), it is worth noting that Pound goes on immediately to justify his proscription in the context of addressing what he does not hesitate to call "an intelligent person" with the primary aim of affirming the dismantling of the simple conflation between "poetry" and "verse" a half-century earlier in Poe's "The Poetic Principle" and "The Philosophy of Composition" that made possible the prose-poetic revolution of $L e$ spleen de Paris. 
More and more we are getting nowhere, and that is a pleasure. ("Music," $57: 19)$

We grow thin by exclusion. ("Music," 58:20)

While the very legitimacy of a poem as poem has come to be associated since Pound in hegemonic fashion with the quality of "images," and while poetry itself has come to be defined as a predominantly image-saturated discourse, it is worth noting that in articulating what he crucially refers to as the "complexity" of the "image," Pound does not define it in a way that would attest to its conceptual purity, affirming its provenance from the history of specifically "poetic" discourse and thus a certain intra-disciplinary authority and autonomy "within" the field of what is called "poetry."

ANYTHING MAY HAPPEN AND IT DOES. . . Listening as ignorance. . . . What we need is irresponsibility... . an upward leap into the air, whatever the consequences. ("Music," 59:21)

... Let's admit that the lines we draw are not straight. After a life of correctly brushed teeth, we prefer parentheses and italics. Rules of misbehavior. . . Ordinary disorder vibrates into surprise. ("Music," 60:22)

Rather than telling us in other words, as it were, on poetry's own terms, what makes a poem a poem, Pound has recourse to a definition, for a specific understanding of what we might call "poetry's image"-the kind of "image" specific to poetry that makes a poem a poem - that depends for its own authority on recent developments within another, newly emerging discipline, the discipline of "psychology": "I use the term 'complex' rather in the technical sense employed by the newer psychologists, such as Hart, though we may not agree absolutely in our application." Where the combined efforts of Poe and Baudelaire contributed decisively to the dismantling of the simple equation "poetry" = "verse," building on 
Wordsworth's "the language of Prose may yet be well adapted to Poetry; . . a large portion of the language of every good poem can in no respect differ from that of good Prose." Pound moves in the opposite direction, crossing disciplinary boundaries between "poetry" and "psychology"-a crossing "natural" enough following Romanticism's affirmation of the poem as above all a form of autobiography - to establish a new doxa, the equation of "poem" and "image," for which the minimalist "In a Station of the Metro" came to serve as a virtually "pure," "conceptual" emblem and exemplum, the very Idea of the image, of the image (almost, but not quite) as Idea, the image of the image of the image ...

So that, again, immediately following, so richly, paradoxically placed under the subheading "Language," Pound delivers his prohibition, not against images but, as if down the from heavens, or from Olympus: "Go in fear of abstractions." Preceding which, as we have now to mention, before any of the above prescriptions and proscriptions, "A Few Don'ts" famously ventures the following: "1. Direct treatment of the 'thing' whether subjective or objective." If such an idea of poetry, as of language generally, was made untenable in advance, and at the very time of its articulation, by the elaboration of modern linguistics inaugurated by his Swiss contemporary, Fernande de Saussure, the consequences of Pound's turn to psychology rather than linguistics could scarcely have been more persistent for American poetry's understanding of its place and purpose among the disciplines, including the current stage of pervasive institutionalization of programs in "creative writing" in the United States throughout higher education, where it has come to dislodge, for the time being it appears rather decisively, the prestige and currency of courses of whatever orientation in "literary criticism" and "theory."

\section{What Then Does the Poet?}


If the chain of associations that leads modern poetry from "things" to "images" to poems as "image-things" or poems as "thing-images" continues to hold sway, that equation is sustained perhaps above all by the reduction of Pound's complex formulation to an affiliated doxa, the conflation of "image" with "emotion," or "affect," that has its roots in an equally diminishing, equally consequential reduction, that of the complex poetics articulated in one of the foundational texts of British Romantic poetry, Wordsworth's "Preface" to the Lyrical Ballads (1798). As the Poundian image has come to be associated in the century since its complex original formulation almost exclusively with "emotion" and the suppression of "abstract" in favor of "concrete" nouns-so the Wordsworthian understanding of poetry has come to be reduced to a distressing extent, despite the efforts of critics and theorists to the contrary, to the "spontaneous overflow of powerful feeling" and "emotion recollected in tranquility." Like Pound's recourse to another discipline, as also his emphasis on the "intellectual," conceptual stakes that give the image its desired complexity, Wordsworth's program for poetry too has tended to be stripped, in its by now two-century reception, of a complexity that involves, even more explicitly and expansively than Pound's definition of poetry, a richly cerebral, multi-disciplinary engagement and contextualization.

Responding to his own fundamentally discipline-oriented questions ("Taking up the subject, then, upon general grounds, let me ask what is meant by language is to be expected from him?") Wordsworth responds by first situating poetry in relation to Philosophy, poetry's traditional discursive Other since Plato's expulsion of poetry from the polis and its subsequent reclamation and reabsorption by Aristotle, to whom Wordsworth attributes (interestingly enough, by hearsay) a dismantling and subsumption of the philosophy/poetrywe could also say of the intellectual/affective, conceptual/affective-binary:

Aristotle, I have been told, has said that Poetry is the most philosophic of all writing: it is so: its object is truth, not individual and local, but general, 
and operative; not standing upon external testimony, but carried alive into the heart by passion.

Immediately following this restaging and dismantling of the initial, ancient, foundational, for all theoretical and practical purposes unavoidable Platonic/Aristotelian discursive-disciplinary binary, Wordsworth complicates poetry's discursive position, in strikingly non-binary, multi-disciplinary terms, attempting to distinguish it from the work of "the Biographer and Historian . . . a lawyer, a physician, a mariner, an astronomer, or a natural philosopher, . . . a Man. " Further contrasting "poetic" knowledge and practice ("What then does the poet?") and that of the "Man of science, the Chemist and Mathematician, . . . the Anatomist's, ... the Botanist, or the Mineralogist," anticipating with considerable anxiety what today we might call the poet's disciplinary status, Wordsworth struggles to lay claim to a specificity of the poetic project that would guarantee both its intellectual/conceptual and emotional/affective authority.

Perhaps the greatest fiction, mythology, ideology that has taken hold in American poetry since Pound is that "true" speech, the truest speech, by which is meant not speech that opens onto ideas but rather, with a more Aristotelian orientation, affective speech, is speech that is said to "reach" what Wordsworth alternately calls "sensations," "sympathies," "feeling," "emotion." In this respect, the dominant ideology of American poetry over the past century inaugurated by Pound's "imagist" proscriptions-ideological precisely to the extent that the dominant poetic culture does not perceive it as ideology, but as truth-has been that linking the hegemony of the "image" with with that of "feeling" tout court.

To write a poem is to write in "concrete" images, and to write in images is to communicate, above all, "feelings," to the exclusion, above all else, of "abstraction," which is to say of abstract nouns, which is to say of thinking, of what Pound called the "intellectual" side of the "complex" character of the "image," which is to say above all of "collective" (sociological) as distinct from "individual" (psychological) thinking, including the orientation of what is called thinking —as philosophy, as theory—toward generalization, classification, 
categorization. Installing, thus, against the "complex" prescription that the "image" should be conceived as at once "intellectual" and "emotional," the virtual apartheid that has come to reign since in the mainstream of modern poetry between poetry and philosophy, Pound continues:

Pay no attention to the criticism of men who have never themselves written a notable work. Consider the discrepancies between the actual writing of the Greek poets and dramatists, and the theories of the GraecoRoman grammarians, concocted to explain their metres.

.... If I try to say the whole thing in one sentence I say the same thing over and over. (72:8)

My writing is nothing but a stutter. (76:12)

\section{The Poet as Contemporary}

Was sind das für Zeiten . . .

Explicitly warning his readers "not to consider such a prescription as 'dogma"'"never consider anything as dogma — but as the result of long contemplation, which, even if it is someone else's contemplation, may be worth consideration"Pound recalls Wordsworth's qualification that the "spontaneous overflow of powerful feelings" is based in "deep thought." Complicating and resisting, in the very moment of his articulation of an "imagist" theory and practice, the subsequent hegemonic alignment of modern poetry with what we might call the affective image, in its most diluted form reduced to mere picturism, the merely visual or "tangible" sensation, Pound anticipates what Jacques Rancière has called, in his trenchant critique of the aesthetic ideology of the later Roland Barthes of Camera Lucida, "the affective power of sheer presence," the 
"punctum" he contrasts with the "studium," which asks to be "decoded and explained." Echoing Pound's "complex" understanding of the image as at once "intellectual" and "emotional," Rancière reminds us of a "specific regime of 'imageness', a particular regime of articulation between the visible and the sayable ... the legible testimony of a history written in the faces or objects and pure blocs of visibility impervious to any narrativization, any intersection of meaning." Attentive throughout to what Rancière calls the "solidarity between the operations of art, the forms of imagery, and the discursiveness of symptoms ... the twofold power of aesthetic images: the inscription of the signs of a history and the affective power of sheer presence," Driven to Abstraction names explicitly, and continues to elaborate decisively, Waldrop's life-long commitment to a poetics of the "image" in the full sense Pound's original definition intends, but with a linguistic self-reflexivity that understands the image's "intellectual and emotional complex" as a "thought-provoking matter," above all, of language.

Against the dominant tendency of modern poetry over the past century toward the diminishment of the Poundian project expansively conceived, Waldrop has continued to elaborate a diverse, ambitious body of work that extends into new territory both the Poundian project of the "complex" image and its Wordsworthian corollary, the Aristotelian understanding of poetry as "the most philosophic of all writing."

The idea that ceaselessly. A string of beads. Of follies. Of particles. . . . Infinite progressions. Delirious possibility. ...

A system of numbers ... conventions of syntax and grammar.

Conventions instead of. ... (91)

What we call the "image" is never, as Waldrop understands with Rancière, "a simple reality." If the term may be said to consist of "several functions whose problematic alignment constitute the labour of art "(1), including especially "operations that couple and uncouple the visible and its signification" (4), Driven 
to Abstraction calls its readers to a full affirmation of poetry's discursive powerbeyond "images" in the narrow sense in which that term has too often come to be conceived - its capacity to be as intellectually and emotionally complex, as at once "conceptual" and "affective," as it is multi-disciplinary, aesthetically, linguistically, philosophically, economically, politically aware and self-reflexive as the medium and history of poetry at its best demand, a measure of our times, of being "contemporary."

Inquiring into the character of the "contemporary" in the third and final section of his recent, dialectically structured work, What Is an Apparatus? (Che cos'è un dispositivo? 2006/2009), Agamben writes, with reference to Roland Barthes' lecture at the Collège de France on Nietzsche's Untimely Meditations (Unzeitgemässige Betrachtungen, 1874): "Of whom and of what are we contemporaries?' And, first and foremost, 'What does it mean to be contemporary?" Whether with respect to texts whose authors are "many centuries removed from us," or others "more recent, or even very recent," it is essential, Agamben argues, "that we manage to be in some way contemporaries of these texts (39). Where Nietzsche could claim a certain need, even urgency to overcome, near the end of the nineteenth century-four decades in advance of the deeply presentist prescriptions and proscriptions of the Poundian image's "direct treatment of the thing', whether subjective or objective"-what he described as being "consumed by the fever of history" (40), Waldrop's Driven to Abstraction suggests a sense of urgency in the opposite direction. Playing off the idiom "driven to distraction," an idiom that seems increasingly and pervasively to define the character of $21^{\text {st }}$-century life "on the Web," Driven to Abstraction extends Waldrop's life-long project of resisting and complicating narrowly reductive image-based procedures in favor of a poetics that situates the present deeply and intricately in relation to the legacies of the past and the promise of a future, in poetry and elsewhere, that would lead us to speak, and write, otherwise.

Understanding "contemporariness" as, in Agamben's sense, "a singular relationship with one's own time, which adheres to it and, at the same time, 
keeps a distance from it," more precisely a relationship with time that "adheres to it through a disjunction and an anachronism," Driven to Abstraction exemplifies Agamben's recognition that "Those who coincide too well with the epoch, those who are perfectly tied to it in every respect, are not contemporaries, precisely because they do not manage to see it; they are not able to firmly hold their gaze on it. (41) Carrying forward her work's ambitious refusal to quarantine poetry within the confines of a narrowly affective understanding of poetry's capacities, placing it always in conversation with the range of discourses, including specifically disciplinary discourses, with which, as Wordsworth gave us to understand in his "Preface" to the Lyrical Ballads, poetry must contend to establish its authority, its contemporariness in the sense Agamben intends with respect to Nietzsche's "actuality" or "relevance" (attualità) and what we might today call its "currency," in the economic sense into which Driven to Abstraction inquires pervasively, most explicitly in "The One Who Counts, Who Paints, and Who Buys and Sells" (89-97), the ten-page section of the first of the title poem's four sections, including "Bank-Money" (96-97); "Paper Money" (109-10), from the second section entitled "What Has Become of the Subject?"); and "Zenomoney: From Promise to Tautology" (129-30), from the third section entitled "Absence of Origin."

If, like The Cantos, Driven to Abstraction attributes great authority to the discipline of economics, it is equally well "a poem including history":

The battle of Agincourt was fought in hours, Waterloo in a day, Gettysburg lasted three days, the Battle of the Somme four and a half months, Verdun ten, Stalingrad six. There were the Seven- and the Thirty-Years Wars. The President told the West Point cadets; 'Iraq is only the beginning."' (79)

From the predominantly past-to-present movement that concludes the book's five-section opening poem, "Sway-Backed Powerlines (2004-2008)," the whole of which moves, albeit in the manner of a Benjaminin Tigersprung, from the 
voyages of Columbus and the conquest of America to the Iraq War, to the pastto-more-distant-past movement of the book's four-section title poem (again from a self-reflexively "present" perspective) from DaVinci and the development of perspective in Renaissance painting to foundational figures in ancient cosmology, philosophy, religion, and mathematics-Driven to Abstraction understands whatever ideas we may have of poetry's "image" as inseparable from an ongoing conversation with other disciplines, including especially physics and cosmology ("All Electrons are (Not) Alike," Time Ravel," "Inventions of Infinity"); mathematics ("A Little Useless Geometry \& Other Matters," "Zero, the Corrosive Number," "Zero, or Closing Position"); psychology/philosophy ("What has become of the Subject?"; and aesthetics, encompassing music ("Music is an Oversimplification of the Situation We Are In"), painting ("Vermeer's The Art of Painting"), literature, reading, and writing ("I Have Made My Booke to No Greater Extent Than My Booke Has Made Me," "Interlude: The Pencil I Chew," "King Lear's Nothing"). As the interweaving and ultimately ambiguously multiple discursive/disciplinary provenances, domains and registers of many of the above titles suggest, the positions Driven to Abstraction negotiates for poetry and poetics among the disciplines, like the relations of discourses and disciplines generally and the book's intricate oscillations between past and present, public and private histories (including frequent references to the speaker's father and mother), remain fluid, unstable, overlapping, its investigations, etiologies and teleologies never final, always provisional, always, above all, to be read, not so much precisely to be "decoded and explained," in Rancière's words, as to contribute to an endless unfolding of language in/and as history, Waldrop understands poetry's drive to "abstraction" as inseparable from its drive to imagination, figuration:

If signs create the very objects they were thought to represent, . . thought provoking matter, then it's illusory to think object come first. . . . An illusion whose nature we had orgotten and therefore took for truth. 
... Blue jeans, babies, barges on the Seine, the gondola on the Moshassuck, bodies in the Tigris? The woman in purple, the man heading into Starbucks, the fish in the water, and the cruise missiles in the sky?

Once literal and figurative, presentation and representation coincide: Zero is again a number among numbers. ... a location among others. . . .

But the subject. Is driven to abstraction. . . Ceaselessly the subject. Absents herself.

The world of things, says Plato, is insubstantial. ... (111)

Can words to the impossible and break through the concept barrier? Can things and the names of things blur the way things and space do? ... Writing's not natural. I stitch it together like the old rhapsodes, The body eclectic. (113)

\title{
Poetry among the Discourses
}

\author{
Wildtexte, die noch vor Zeiten weite Teile Europas \\ besiedelten, haben sich mittlerweile den immer \\ spezielleren Anforderungsprofilen unterworfen. ... Im \\ Laufe seiner innigen Partnerschaft mit dem Text hat der \\ Dichter bestimmte Eigenschaften gefördert, gemindert \\ oder vermischt und so eine stattliche Anzahl von \\ lyrischen Typen geschaffen. \\ Ulf Stolterfoht, Das deutsche Dichter- \\ abzeichen (17)
}

Reviving in "What Is an Apparatus?" Heidegger's questions concerning poetry, philosophy, and technology, Agamben writes:

It would probably not be wrong to define the extreme phase of 
capitalist development in which we live as a massive accumulation and proliferation of apparatuses. . . today there is not even a single instant in which the life of individuals is not modeled, contaminated or controlled by some apparatus. In what way, then, can we confront this situation, what strategy must we follow in our everyday hand-to-hand struggle with apparatuses? What we are looking for is neither simply to destroy nor, as some naively suggest, to use them in the correct way.

... At the root of each apparatus lies an all-too-human desire for happiness. The capture and subjectification of this desire in a separate sphere constitutes the specific power of the apparatus. [17]

What kind of an apparatus, then, is a poem, and what, in Agamben's revisiting of Heidegger's questions, are poets for? If, as Agamben argues, "terminology is the poetic moment of thought," which nevertheless does not say " that philosophers must always necessarily define their technical terms," as "Plato never defined idea, his most important term" (3), what may be said to characterize Driven to Abstraction perhaps above all, and most impressively, interwoven throughout with its sustained attention to poetry's place among the discourses and engagement with other disciplines (if poetry may be said to be a "discipline"), is its sustained attention to questions of language, to poetry and poetics as an art and science of signs in the most capacious sense of the word.

Developing his idea of the "contemporary" with reference to Osip Mandelstam's 1923 poem, "The Century," Agamben writes that in figuring "the backbone of this age" as "shattered," the poet, "insofar as he is contemporary, is this fracture, is at once that which impedes time from composing itself and the blood that must suture this break or this wound" (42). He continues:

The poet—-the contemporary—must firmly hold his gaze on his own time. But what does he who sees his time actually see? .... The contemporary is he who firmly holds his gaze on his own time so as to perceive not its 
light, but rather its darkness. ... the contemporary [the poet] is the person who perceives the darkness of this time as something that concerns him, as something that never ceases to engage him. (44-45).

The burden, or gift, of contemporariness, "inscribes itself in the present," Agamben argues, "by marking it above all as archaic . . The present is nothing other than this unlived element in every thing that is lived." (50-51).

Reading Driven to Abstraction in light of this understanding of the poet's work-the task Agamben does not hesitate to assign to the poet, the true "contemporary" who "makes of this fracture a meeting place, or an encounter between time and generations" and thus intervenes, in redemptive fashion, in what he calls with Benjamin "messianic time," the "time of the now" (51) - it is tempting to understand the book's title as an overcoming of the idea of the image, narrowly conceived, through a counter-investment in the idea of the idea, Plato's "most important," yet forever undefined term. To read Waldrop's work as a redemptive suturing of this binary, of "image" and "idea," would nonetheless betray what is arguably the book's most important contribution, namely, its refusal, in the name of the endless multiplication, subtraction, and division of signs, of language as boundless potential to provide alternative logic(s), logics other than binary_not reducible, for example, to the dialectic of "darkness" and "light" with which Agamben brings to a theological close his reflection on the "contemporary," the logic as well of Agamben's insistent recourse to the rhetoric of the "on the one hand"/"on the other hand" (no phrases occur more frequently in The Future of the Image)—other than dialectical, other than oppositional, logics that would elude capture even by the book's alluring yet limited closing imperative: "Contradict as needed" (133).

What may be said to characterize Driven to Abstraction perhaps above all, and most impressively, together with its sustained attention to poetry's place among the discourses and engagement with other disciplines, is its sustained attention to questions of language, to poetry and poetics as an art and science of signs in the most capacious sense of the word. 
... A Absence of things, of signs. Unnatural. . . .

... A signifier with a shape that could be traced in 'learned dust,' on wax, on paper. A body unbound by words like nihil, niente, nada, nothing, nichts, and even zilch.

Like the phoneme that makes possible language. Neither physical nor psychological reality, but a value with an abstract and fictive importance. That enables. (115)

"When I say poetry is an exploration of language," Waldrop earlier wrote in "Alarms and Excursions," it is not a retreat from the social, because language is the structure that is shared by society and this otherness that is poetry. It also does not mean that there is no reference. It means that references is secondary, not foregrounded. The poem works by indirection, but the poet's obsessions and preoccupations will find their way into the text." (Dissonances, 171-72).

If, as Agamben asserts with Benjamin, "the historical index contained in the images of the past indicates that these images may achieve legibility only in a determined moment of their history," and if it is contingent on us to develop our capacity "to respond to this exigency ... to be contemporaries not only of our century and the 'now,' but also of its figures in the texts and documents of the past" (54), Waldrop's consistently complex, linguistically self-referential, multidisciplinary investigations, which understand "images" and "ideas," "affect" and concept," as inseparably interwoven, offer an alternative akin to Agamben's invocation of the typos or "figure" (53), yet in an other-than messianic way that includes the open-ended promise, at once "image" and "idea," less a final "redemption" than an ongoing conversation - of what we might call a continuing, a way of thinking, feeling, imagining, using language that elaborates topoi other than Agamben's opposition between "the darkness of the present" and "a light that can never reach its destiny." (54). 
Understanding "images" and "ideas," "affects" and concepts," as inextricably interwove, Waldrop's consistently complex, linguistically selfreferential, multivalent, multi-disciplinary investigations offer an alternative logic of continuing, of thinking, feeling, imagining language in ways more intricate, subtle, and inclusive than instrumental, adversarial uses of language allow. If Waldrop is "the one who, dividing and interpolating time, is capable of transforming it and putting it in relation with other times," who is "able to read history in unforeseen ways, to 'cite it' according to a necessity that does not arise in any way from [her, not his] will, but from an exigency [Driven to Abstraction] to which [she, not he] cannot respond," her other-than "theoretical" [yet not nottheoretical] interrogation, she is also the one who teaches us how to respond to our "determined moment" of history, to be "contemporaries not only of our century and the 'now,' but also of its figures in the texts and documents of the past...." (54)

It is supremely difficult, as Waldrop give us to understand, to develop a language other than that of the "not/but," the "either/or," even the "both/and." Yet perhaps nothing, in our time of the "now," could be more urgent, could drive us more thoroughly to distraction, if not collective self-annihilation. To say, I don't say not, but other than, "contradict as needed," to speak, to write otherwise:

Power of writing. Or toughness of paper? kein ding sei wo das wort gebricht. No thing without words, no fact before, no fact before signs, no specie, no prior body? The signs I write down here preceded by signs? Turtles all the way down? In signs we trust. To build balconies out over the void.

Many have thought the voice might save the body. From the abstractions we live in....

... If there is no redemption by voice any more than by gold. If signs are irreparably dislocated from what I supposed to be their signified. How 
instantly then our writing, like our knowledge, becomes subject. To ever new interpretations and directions. Unsuspected futures. Off-shore versions of its previous self?

... At the bottom of any thing I find a word that made it. And I write. Have made a pact with nothinggness. Make love to absent bodies. And though I cannot fill the space they do not occupy their shadows stand between me and thin sky. (131-32)

"Contradict as needed." An invitation, then, not so much to write against, to contest, as opposed to, not for naught, not for knots, not for nothing, so much as for speaking and writing alongside, adjacent to, even with. That is the challenge, and opportunity, Waldrop's work presents to us, to think, to feel, to imagine, to use language in ways irreducible to the binary "clashes" Rancière characterizes as the obsolescent "avant-garde" poetics of a certain modernist aesthetic regime. If ours is time when, as Rancière argues, "the age of images is behind us," the further development of an appositional poetics, of which Driven to Abstraction provides a exemplary typos, is a promising place to begin.

Thus Ulf Stolterfoht, in fachsprachen (Lingos)—a nine-year project encompassing four books of nine parts each for a total of 36 parts (I-IX, 1998; XXVIII, 2002; XIX-XVII, 2004; XVIII-XXXVI, 2009)—at once assembles and dismantles poetic "objects," poems-as-things. Inviting and at the same time defying hermeneutic appropriation, coherence, cogency, argument, and intelligibility, from the most micro- to the most macro- levels, both syntactically and semantically, Stolterfoht's parodic interanimations and disassembling of every kind of specialized language, including that of poetry, call into question the very plausibility of anything like a Bakthinian "speech genre," as well of individual speakers as "ideologues." As with Hejinian's notion of poetry as a "language of inquiry," the ceaseless questioning of language enacted in Stolterfoht's fachsprachen is not so much a questioning of the utility of poems as poems, but a questioning in and by texts that agree to "look" and "sound" like "poems" of the 
very idea of the utility of what Agamben calls the "massive accumulation and proliferation of apparatuses," in the case of Stolterfoht's "lingos," of languageapparatuses conceived of precisely in and as a wild variety of unruly, always already overdetermined, forms:

muttersprache 1972/2:

materialwiderstand

wörter fallen nicht vom himmel. historisch wachsen

sie heraus. das dauert. bis (unmündig aber selbstver-

schuldet hörig) zu den knöcheln im tier das sprießen

der geweihe tritt-ein magischer moment: der wolf

gerade dann heranrennt wenn man nennt—bleibts einem engländer vergönnt "dem spekulativen begriffsgebäude der scholastic den entscheidenden stoß zu versetzen": nichts stehe mehr für anderes! was marktkonform sofort

gedichtverknappung zeitigt. da aber hinterkopf reserve "im" bald schwerer wiegt als heute wert papier gedanke "auf" spricht manches für nicht nur: erzeugerseits betrieben. fast sicher künstlicher natur zeigt funktionalen

riecher. in ähnlich einprägsamer formung geht längst ein unwort um an neckar spree und ruwer: von gegenstrebiger vereinigung wie der des reihers mit dem rogen / in hergebrachter sage: staatlich gestützter prosa-verstromung.

beginn des großen dichterdarbens. leicht für die wörter mit dem wolf zu heulen. hysterisch schnüren sie heran. 
gewaltverhältnis ungeklärt. ihr gut verzahnter fang: erzeu-

gerzugewandt! zeigt sehr wahrscheinlich rißbereitschaft an. (83)

muttersprache 1972/2:

material resistance

words don't drop out of the sky. from history they grow. which takes forever. until (under age but self-enslaved) animals beside their ankles sprout antlers-magic moment: the wolf comes running

just when one cries wolf-leave it to an Englishman to 'give scholasticism's speculative system the coup de grace': let nothing stand for nothing else! the market promptly reacts with poetry cutbacks. but

since brains (reserves 'in') then are valued almost more than bond paper (thoughts 'on') there's much to be said for not just: supply-side. almost certainly artifice but a nose for what will work.

likewise a memorable non-word has long been circulating round the rivers neckar ruwer spree: a joining against the grain as that of egret and roe/ in plain speech: state-supported verstromung-prose.

begins the great poet famine. easy for words to howl with the wolves, hysterically they start to dart. power relation unclear. their sharp-toothed jaw: producer-friendly! likely ready to tear you apart. (84) 
Stolterfoht's poems, like Waldrop's, but with relentless linguistic self-parody, are not content to be "poetic" things as such, to play the instrumentalizing, noninstrumental role of poetry as Zweckmäßigkeit ohne Zweck. Their playfulness questions the purposes of a poem as one kind of language-apparatus, however heterogeneous, among others, as of all language-apparatuses in a general economy of the kind Agamben describes, an economy Stolterfoht figures in the above poem's conceit linking the rapaciousness of capitalism and animality. Whatever kind of thing a poem might be, in the hands of Stolterfoht, as of Waldrop, it aspires to be other than that. Not an answer, but a question. Not Truth, but an unsettling at the core of its values, not a thing in itself but a form of self-questioning, of all discourses, all disciplines, that "thing" that binds poetry and philosophy together, as urgent matter, in continuing:

\section{zwei satzstöcke für gottlob frege}

Russell: wenn ich über beispiele von integrität und würde nachdenke so wird mir klar daß ich nichts kenne was sich mit freges unbeirrbarer wahrheitsliebe vergleichen ließe. (...) als er nun feststellte daß seine

fundamentale voraussetzung falsch war antwortete er darauf mit intellektuellem vergnügen wobei er offenbar jeden anflug persönlicher enttäuschung unterdrückte. das war fast übermenschlich und ein bedeutsamer hinweis

wozu menschen fähig sind wenn es innen um schöpferische arbeit und erkenntnis geht. Wittgenstein: nach meinem letzten zusammentreffen mit frege standen wir am bahnhof und warteten auf meinen zug. da sagte ich zu ihm: sehen 
sie eigentlich nie die geringste schwierigkeit in ihrer

theorie wonach die zahlen gegenstände seien? er ant-

wortete: manchmal kommt es mir so vor als sähe ich da

eine schwierigkeit aber dann sehe ich sie eben doch nicht. (121)

\section{two sentence blocks for gottlob frege}

Russell: as $i$ think about acts of integrity and

grace I realize that there is nothing in my

experience to compare with frege's dedication

to truth. (...) on finding that his fundamental

assumption was in error he responded with

intellectual pleasure clearly submerging any

feelings of personal disappointment. this seemed

almost superhuman and remarkable evidence

of what men are capable of when creative work and knowledge are at stake. wittgenstein: after my last meeting with frege we were at the station waiting for my train. I said to him: do

you really never see the slightest difficulty with your theory that numbers are objects? he replied: sometimes I almost feel as if I saw a difficulty but then I do not see it after all. (115) 
Works Cited

Agamben, Giorgio. "What Is an Apparatus?" In What is an Apparatus? and Other Essays. Trans. David Kishik and Stefan Pedatella. Stanford, CA: Stanford University Press, 2009. / Che cos'e un dispositivo? Rome: Nottetempo, 2006.

. "What Is the Contemporary?" In What is an Apparatus? and Other Essays. Trans. David Kishik and Stefan Pedatella. Stanford, CA: Stanford University Press, 2009. Che cos'è il contemporaneo? Rome: Nottetempo, 2008.

.What Is an Apparatus? and Other Essays. Trans. David Kishik and Stefam Pedatella. Stanford: Stanford University Press, 2009.

Brecht, Bertolt. "An die Nachgeborenen." An die Nachgeborenen first published in

Svendborger Gedichte (1939) in: Gesammelte Werke, vol. 4, pp. 722-25 (1967)(S.H. transl.) . "Schlechte Zeit für Lyrik" (1938). Gesammelte Gedichte. Bd. 2. edition Suhrkamp,Frankfurt a. M., S. 743-744.

Celan, Paul. "Weggebeizt." In Atemwende. Frankfurt am Main: Suhrkamp, 1967. Heidegger, Martin. "What Are Poets For?" Trans. Albert Hofstadter. In Poetry, Language, Thought. New York: Harper Perennial, 2001, 1971. / "Wozu Dichter?" In Holzwege. $1^{\text {st }}$ edition; Frankfurt am Main: Klostermann, 1950. “The Question Concerning Technology” (1950). Trans. William Lovitt. In The

Question Concerning Technology and Other Essays. New York: Harper Perennial, 1977. / "Die Frage nach der Technik." Vorträge und Aufsätze. Pfullingen: Verlag Günther Neske,1954. Also in Die Technik und die Kehre. Pfullingen: Verlag Günther Neske, 1962.

Hejinian, Lyn. The Language of Inquiry. Berkeley: The University of California Press, 2000.

Kittler, Friedrich. Discourse Networks, 1800 / 1900. Stanford, CA: Stanford University Press, 1990. / Trans. Michael Metteer, with Chris Cullens. Foreword by David E. Wellbery. Aufschreibesysteme, 1800/1900. Paderborn: Wilhelm Fink Verlag, 1985, 1987.

Pound, Ezra. “A Few Don'ts by an Imagiste." Chicago: Poetry, 1913.

Rancière, Jacques. Le destin des images. Paris: Editions La Fabrique, 2003 / The Future of the Image. Trans. Gregory Elliott. London: Verso, 2007. 
Reed, Brian M. Phenomenal Reading: Essays on Modern and Contemporary Poetry.

Tuscaloosa: University of Alabama Press, 2012).

Stolterfoht, Ulf. Das deutsche Dichterabzeichen. Leipzig: Reinecke \& Voß. 2012 (Hörspiel, SWR, 2009). . fachsprachen I-IX. Gedichte. Solothurn: Urs Engeler, 1998. . Lingos I-IX. Trans. Rosmarie Waldrop, Providence: Burning Deck Press, 2008.

Waldrop, Rosmarie. "Alarms and Excursions," Dissonance (if you are interested). Tuscaloosa, Alabama: The University of Alabama Press, 2005.

_. Driven to Abstraction. New York: New Directions, 2010.

Wordsworth, William. "Preface" to the Lyrical Ballads. London: 1798. 